> combinations rather than individual blocks did the trick - and younger kids were more skilled than older ones at finding unlikely options.

She also cites a number of studies on play, which is so crucial to human development that children engaged in it even in Nazi concentration camps. Research on dolphins, crows and foxes reveals how playing at hunting, digging and fighting develops the skills the animals need as adults. Through play, young rats produce chemicals called cholinergic transmitters, implicated in plasticity in 'social' areas of the brain. Rats deprived of play when young can defend, attack or approach others

\section{"Gopnilk can} be scathing in her censure of the modern educational system." fail to know "when to do what", she notes. Most human parents, Gopnik writes, "have a vague sense that play is a Good Thing". But as an aim of parenting, play is paradoxical, she claims, because it is essentially goalless. Elizabeth Bonawitz, a researcher in computational cognitive development, found that when adults instructed children on how to play with a squeaking toy, the children imitated them. When left to their own devices, the children were more likely to try different actions until they had discovered everything the toy could do.

Gopnik can be scathing in her censure of the modern educational system, which increasingly stresses high-stakes testing. That trend, she notes, parallels the rise in diagnoses of attention deficit hyperactivity disorder (ADHD), which in the United States particularly is often treated with drugs that can have serious side effects, including addiction. More palpable, however, is her devotion to the subjects of her research, including her grandchildren Augie and Georgie, her "true muses", whose antics pepper her text.

Those antics remind me of my own delightfully disorderly, creative five-yearold twins and their in-the-now mischief and affection. As Gopnik concludes: "The most important rewards of being a parent aren't your children's grades and trophies - or even their graduations and weddings. They come from the momentby-moment physical and psychological joy of being with this particular child, and in that child's moment-by-moment joy in being with you."

Josie Glausiusz writes about science and the environment for magazines including Nature, National Geographic and Hakai. Twitter: @josiegz

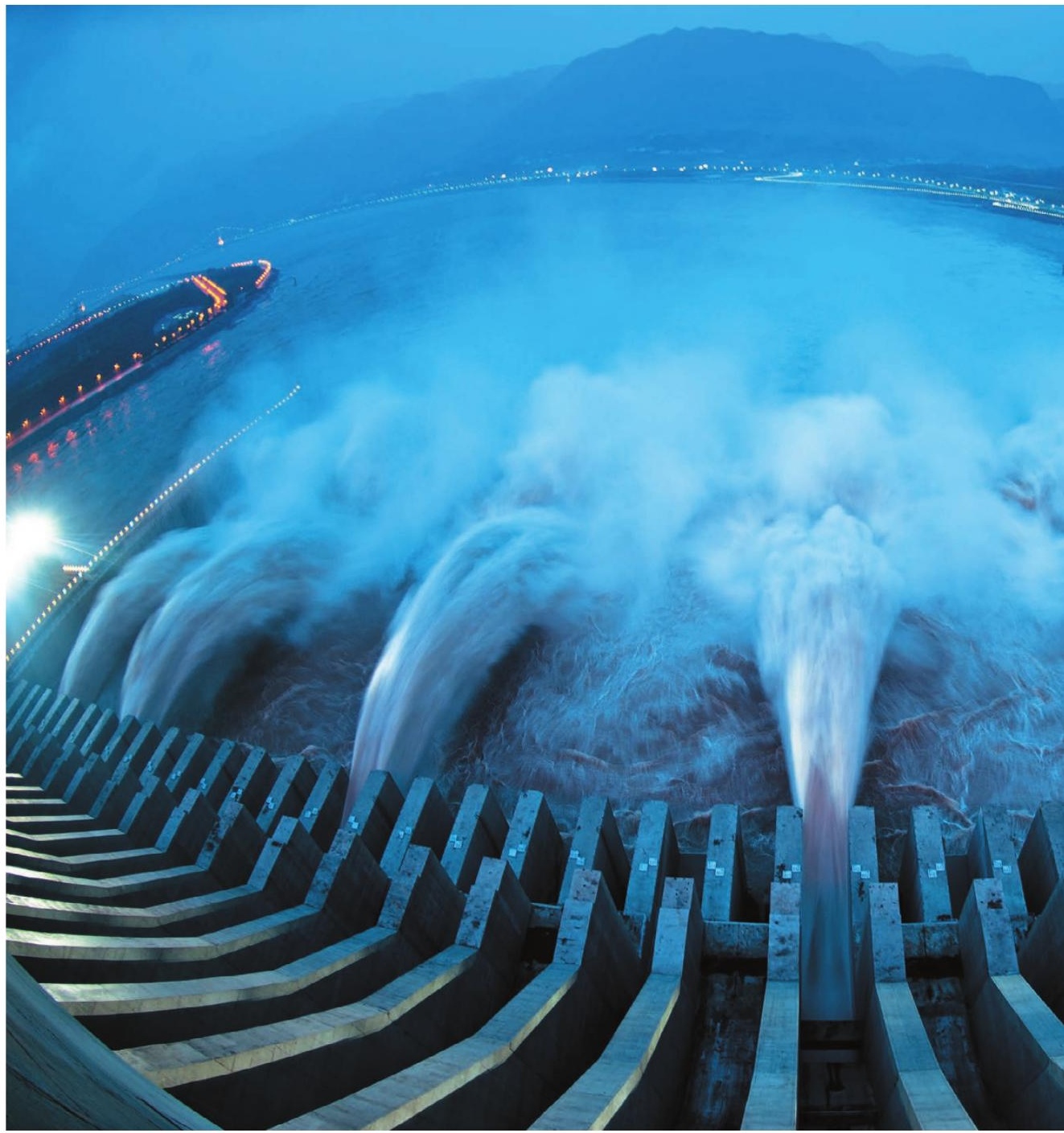

The Three Gorges Dam on the Yangtze River is one of the world's largest power stations.

\title{
CHINA
}

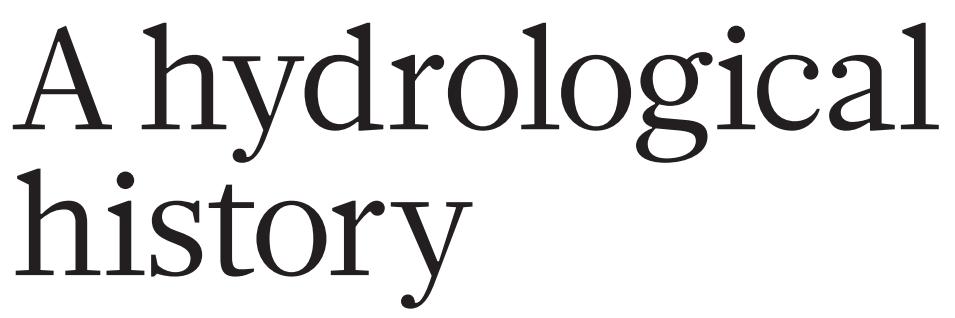

\section{Andrea Janku enjoys a study of the nation-building role of China's great rivers, the Yellow and the Yangtze.}

$\mathrm{N}$

early 70 years ago, Chinese anthropologist Fei Xiaotong published From the Soil (1947). The Chinese people, he wrote, were "inseparable from the soil", which had produced "a glorious history", but one that was "limited by what could be taken from the soil". If that book was the portrait of a rural and inward-looking country, literally stuck in the famous yellow earth the loess of the North China Plain - science writer Philip Ball's history of China, The Water Kingdom, is very much the opposite.

It is the portrait of a civilization permeated by water, with patterns of thought influenced by the centrality of water to everyday life and, echoing that, practical affairs shaped by philosophical ideas based on the principle of flow. The result is, Ball writes, "an intimate connection between hydraulic engineering, governance, moral rectitude and metaphysical 


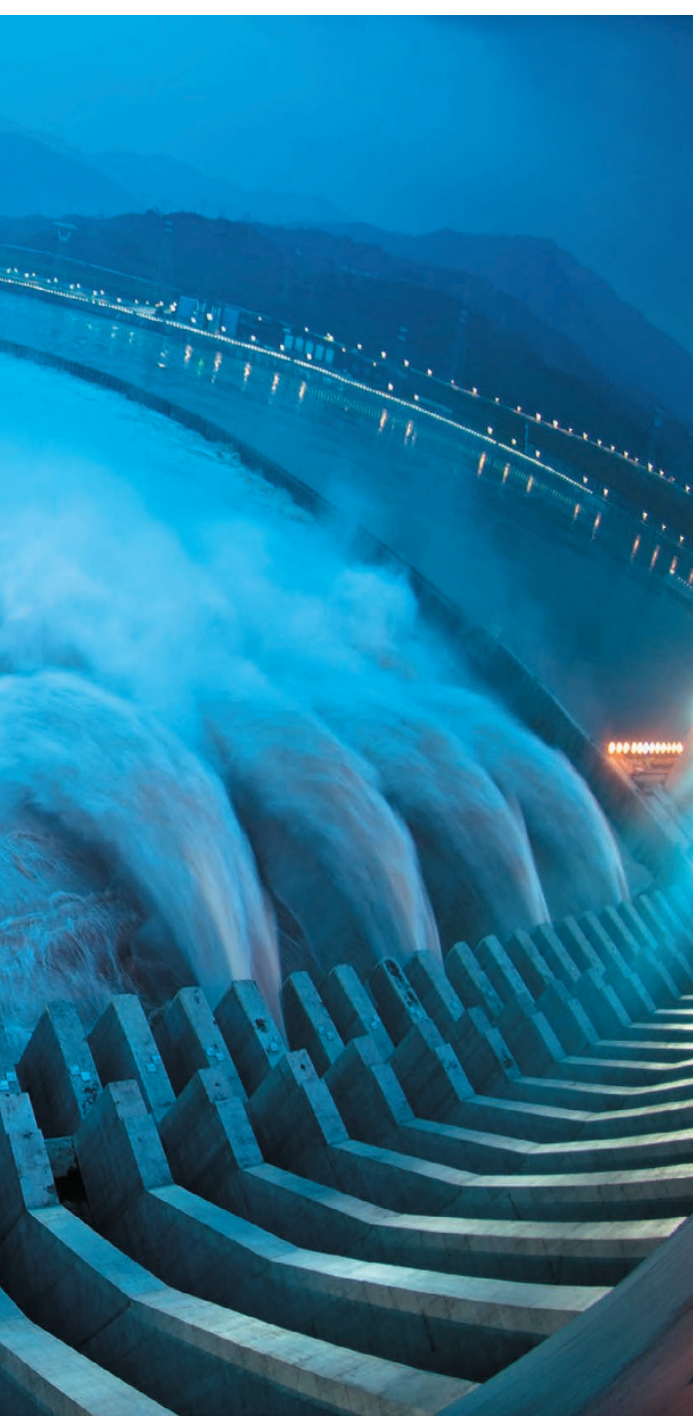

speculation that has no parallel anywhere in the world". On this premise he builds a picture of the nation, from its geographical and ideological foundations to the environmental and political predicament in which China (and not only China) now finds itself.

The Water Kingdom's structure is predominantly thematic rather than chronological. So the first chapter, introducing the Great Rivers, the Yangtze and the Yellow, leads from the Great Yu, the mythical ruler who, according to tradition conquered the floods more than 4,000 years ago, to twentiethcentury Communist leader Mao Zedong, who repeatedly reasserted his power by swimming in the Yangtze. It interweaves more stories of the Yangtze: seventeenthcentury explorer Xu Xiake's search for its source, twelfth-century poet Lu You's descriptions of commercial life along its banks, and more recent Western visitors' accounts of the colossal Three Gorges Dam.

On this epic journey, Ball explores mythological accounts of dragons and floods, along with early philosophical texts such as the teachings of Mencius from the fourth century BC, to unravel the origins of Chinese political ideology. That is, the idea that he who controls the water controls the people, which links the earliest cultural heroes to modern leaders from Republic of China founder Sun Yat-sen to Mao himself. Ball subsequently covers Zheng He's maritime explorations at the height of Ming-dynasty power in the fifteenth century, and the centrality of the Yellow River-Grand Canal administration to the state bureaucracy in the eighteenth. He notes how the late empire turned into a "hydraulic state", increasingly mired in systemic problems that finally collapsed under the pressure of internal rebellion and the imperialist onslaught.

The centrality of water even plays out in the art of war, to which Ball devotes a chapter. In some of the most dramatic conflicts, rivers were harnessed as weapons. In 204 BC, for instance, an intentional rupturing of the Wei River dams led to the victory of the Handynasty forces. And in 1938, the Nationalist government attempted to stop the advancing Japanese army by breaching the Yellow River dykes, with disastrous consequences for the Chinese people - killing hundreds of thousands and making millions homeless. Technological and political parameters changed fundamentally in the twentieth century, yet hydraulic nation-building and the myths that surrounded it assumed an ever more important role. Mao in particular relished the role of the great leader conquering the floods. Ball ends that strand of the narrative with the Three Gorges Dam, first conceived by Sun Yat-sen and finally completed in 2012. He even covers the depiction of water in Chinese art through the ages, exploring its aesthetic, philosophical and political dimensions. The journey ends with a pertinent chapter on China's current environmental crisis. Another hydraulic-engineering project on an unprecedented scale, the South-North Water Transfer Project, is now under way, meant to tackle water scarcity in the north

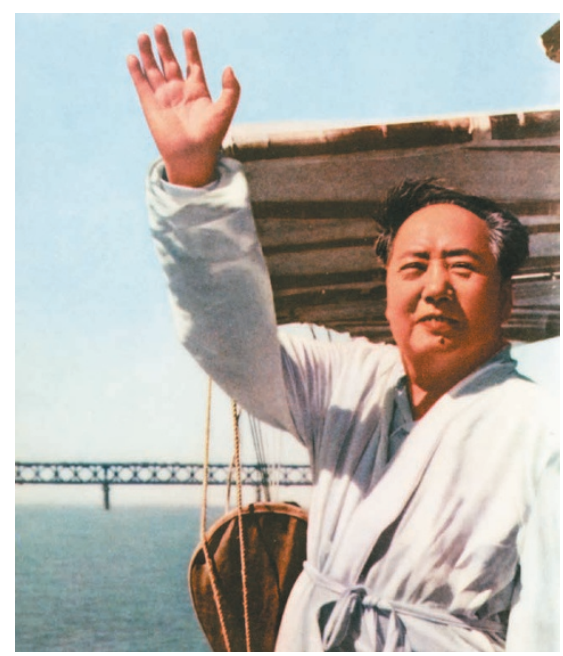

Mao Zedong by the Yangtze.

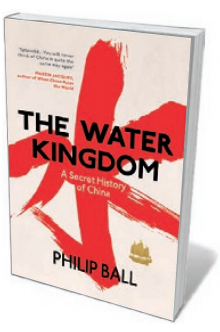

The Water Kingdom: A Secret History of China PHILIP BALL

Bodley Head: 2016.
(J. Barnett et al. Nature 527, 295-297; 2015).

Telling the history of Chinese civilization from the perspective of water is rewarding, because it can link the history of ideas and beliefs, technology and warfare, politics and the arts. But as with any general history, it risks essentializing China and making its history seem more uniform than the actual record justifies. The most obvious example is the major shift in the history of the Yellow River in the late tenth century. It is only from then that the river became a constant threat, bursting its dykes and flooding the countryside in ever more devastating cycles, and changing its course repeatedly in dramatic ways after nearly a millennium of relative stability. And so it is also only from then that controlling the river became tantamount to controlling the people, and that state and society became trapped in an increasingly unsustainable hydraulic infrastructure. That complex system of dykes and canals, with the Yellow River and the Grand Canal at its heart, devoured enormous resources - a quandary called "technological lock-in” by historian Mark Elvin. Moreover, Ball's focus on the state means that he fails to mention the role of small-scale irrigation and conservation projects that are common in particular in the southern China, and largely managed and funded by the local gentry.

Still, this is a convincing introduction to Chinese history. Rather than perpetuating stereotypes, it boldly navigates the treacherous and often-avoided terrain long dominated by influential but spurned theories, such as the idea, promoted by sinologist Karl August Wittfoge, of China as a despotic hydraulic society. It also complements and complicates Fei Xiaotong's idea of an earthbound civilization - a metaphor that has had a huge impact in China itself. In 1988, the six-part Chinese television documentary River Elegy depicted the country as weak and backward, closed off from the world by the Great Wall and stuck in the mud of the Yellow River, contrasted with a progressive, open, oceanic conceptualization of Western civilization. It has taken a generalist to turn the rich but rather dry literature on the history of water in China into an accessible history. Why it is a secret one, however, remains a mystery.

Andrea Janku is senior lecturer in Chinese history at SOAS, University of London. She is currently working on a monograph on the history of famine, Integrating the Body Politic.

e-mail:aj7@soas.ac.uk 